\title{
The Relationship between Reputation, Customer Satisfaction, Trust, and Loyalty
}

\author{
Roshana Gul \\ MS Scholar, Department of Management Sciences \\ National College of Business Administration \& Economics \\ Bahawalpur Campus, Pakistan
}

Accepted: September 22, 2014

Doi:10.5296/jpag.v4i3.6678 URL: http://dx.doi.org/10.5296/jpag.v4i3.6678

\begin{abstract}
Though a lot of studies have been done to conclude customer loyalty as dependent variable but still there is a vast margin of researches to be conducted in future in different spheres of this construct. On the other hand the truth of the importance of customer loyalty as an enduring asset cannot be falsified. It is fundamental for organizations to build up long term and mutual beneficial associations with the customers. The purpose of this research paper is to show the inter relationship of reputation, customer satisfaction and trust on customer loyalty. According to the observations reputation is the major independent variable that has significant relationship with customer satisfaction, customer loyalty, and trust. Data for this research study was taken from the Islamia University, Quaid-e-Azam Medical College, and different banks located at various geographic locations of Bahawalpur region of Pakistan. Data was collected through self administered questionnaire and analyzed by using regression through SPSS. The results have been drawn from 150 users of NISHAT LINEN and it was found that there is positive and significant relationship among reputation, customer satisfaction, trust and customer loyalty. Hence the studies give the positive sign that with the increment of reputation, customer satisfaction and trust the customer loyalty enhances.
\end{abstract}

Keywords: Reputation, Customer Satisfaction, Trust, Customer Loyalty 


\section{Introduction}

The most critical issue in organizations to be measured is customer loyalty. It is necessary to create customer loyalty due to the intense competition and saturated market situations. The world is turning towards the loyal customers from satisfied ones as it is the most integral part of the present businesses. In the era of extreme competition, research concludes that building of durable customer relations for long lasting business is mandatory for managers. It is the matter of concern to find out whether loyalty is a behavioral measure or an attitudinal measure. Nowadays consumers consider their requirements more than usual and they are highly expecting the spectacular standards of service (Chen, Mei-, Fang and Mau, 2007).Customer loyalty measures are different in different fields. In 2004 Beerlie et al assumed another dimension of loyalty and recognized it as essential dimension, it defined loyalty as habitual and further claimed that staying with a definite trademark is better for a customer than consuming energy to change it. Cumulatively most of the researchers have discriminated between interactive and effective loyalties. Here we take the example of bank for understanding both concepts. In Interactive loyalty the customer desires to use the bank in future as well, whereas effective loyalty describes the extent a customer desires to use the bank and the attitude what the bank is. Bloemer et al. (1988) explains that the outcomes from studies on service loyalty could not be pertained to product loyalty, as service loyalty applied to customer-clerk connection.

In this research paper I will discuss the inter relationship of reputation, trust and customer satisfaction and its affect on customer loyalty. I have studied the different researches of various products and services to prove the relationships. Customer loyalty as a research question is not new and past researchers have studied an arrangement of aspects leading to customer loyalty, such as customer satisfaction, service quality, switching barriers and trust. Sustaining the present customers is mandatory for saturated service organizations such as mobile. Hence customer loyalty is an exceptionally vital issue for mobile service providers. Rather, in mobile marketing customer behavior investigation, extreme attention has been given to preliminary adoption and acceptance whereas a bit has to after purchase concepts, like customer satisfaction and customer loyalty (Varnali and Toker , 2009). In many researches, we pay attention to customer loyalty in the sector of mobile communications. From customer's point of view two dimensions of service influence the decision to linger or to leave: what compels a consumer to stay, and the costs that are tangible and intangible to switch to another provider. The previous one is a pull-in force, at the same time the next is a push-back force. Satisfaction and trust includes the pull-in force in relationship quality. There is normally no reason for satisfied and contented customers to leave. No doubt a favorable reputation makes firms able to charge high prices, and give the competitors tough time to compete and create motivating impact on the firms (castro et al,2006). Simultaneously there are advantages for those organizations that are able to sustain and create trust of high level for their organizations among customers (keh and Xie 2009 ;Lacey 2007). Organizations who are able to create trust for its corporate brands can reap marketing benefits and a huge number of customer retention (Lacey 2007).

Market profitability and share is positively correlated with customer loyalty and Customer 
satisfaction. Therefore, distinct competencies have been established by many firms to measure customer satisfaction and equally the whole consulting industry has emerged to get sufficient customer satisfaction. Despite the fact a number of ways are there that define the customer satisfaction, the high-level conceptualization that gains the broad recognition states that satisfaction is a customer's post purchase evaluation of a product or service (Westbrook and Oliver, 1991; Cronin and Taylor 1992).

Repeat sales are generally advanced by customer satisfaction that is major determinant of customer loyalty, and positive word-of-mouth. Brand loyalty can be created by customer satisfaction and it plays one of the key roles as antecedent of creating loyalty among customers. (Cronin , Brady \& Hult 2000; Dick and Basu 1994; Syzmanski and Henard, 2001). The customers who are satisfied come back and buy more and tell others about the experiences, whether it is positive or negative (Fornell et al., 1996). According to Hirschman's (1970) theory of exit-voice, the consumers with weak dissatisfaction would have primary significance for an organization. While the exit option is the choice of strongly dissatisfied customers (i.e., to leave the organization), there is a probability to stay loyal with an organization for those who are weakly dissatisfied customers and somewhat employ the voice option, that involves overt complaints as a trail to change the organization's practice or offerings (Fornell and Wernerfelt, 1988). Whereas, it is the surety for weak dissatisfied customers to become loyal by managing the complaints properly, that serve as an exit barrier (Halstead and Page, 1992; Fornell, 1992). The loyal customers holds considerable impact; in a number of organizations, the profitability increases with the proportion of increasing loyal customers and the new customers generate $60 \%$ of sales and the considerable share goes to the word of mouth referrals (Reichheld and Sasser, 1990).

A firm's mechanism of promising trust worthy behavior is often considered as reputation. In the markets of services and products, the organization's name is frequently used as the brand name across a range of product classes. The company reputation in such circumstances acts like the umbrella brand regarding these product categories (Cretu and Brodie, 2007). The belongings regarding reputation in the minds of customers about a retailer influences the value about the purchases from that retailer (Brown and Dacin, 1997). Customer's perception about a brand having good reputation is as reliable as compared having a poor reputation. Moreover, brand reputation is the substitute for product quality when inherent cues or attributes are complex to employ (Kirmani and Rao , 2000). While exposing the complex market signals, customers may not employ in elaborate information processing. To keep away from overloaded information and any consequential dysfunctional results, the buying decision must be simplified by only attending to a knocking evaluative criterion just as brand reputation. A good reputed product will diminish the perceived risk connected with performance vagueness and information symmetry that lead to positive purchase and repurchase intent. Hence, the proposed definition by Castro et al .(2006) can be considered as follows "the collective representation of actions and outcomes of the past and the present of the organization that describes its capability to obtain valuable outcomes for different stake holders that has to be used in that research. The other authors (e.g. Rose and Thomsen 2004) have also described the same features of reputation as described by the Fomburn. He 
emphasizes the future and past, and at the same time with the diverse stakeholders in forming reputation (Fomburn and shanley, 1990). Finally as it is described by castro et al, (2006) the corporate reputation is a broad concept that integrate the multiple dimensions of a firm and its stakeholders to differentiate between reputations from only the corporate image.

It has been identified that customer loyalty's major driver is trust (e.g. Chaudhuri and Holbrook 2001; Garbarino and Johnson, 1999). He who trusts in a product have more chances to develop favorable attitudes for it, ready to pay a premium price, to be loyal to it, and finally utters positive word-of-mouth (Chaudhuri and Holbrook, 2001). Just like loyalty, trust is known as a psychological state that only occurs in certain relationships. A customer is confident when trusts an organization, product quality and service quality. Having the state of Trust customers tend to be more loyal towards an organization. In Chinese mobile the trust is found in instant message users a leading factor to customer loyalty (Deng et al., 2009). It is pointed out that the customer trust is prerequisite for customer loyalty. Trust has been conceptualized as antecedent of satisfaction in early researches. It has also broadly recognized as antecedents of brand loyalty (Cronin, Brady \& Hult, 2000; Dick and Basu , 1994; Syzmanski and Henard, 2001). In this research I am interested in the direct effects of satisfaction and trust, as components of reputation on customer loyalty. In the academic literature there is consensus on the advantages of sustained positive publicity for the corporate brand. A lot of studies on this topic have made us able to comment that reputation creates value for the firms. (Percy and Elliot 2007; fombrun et al 2000; castro et al, 2006). The research is based on the fact that brand trust and corporate reputation is highly important in order to build a profitable enterprise. A less attention has been paid towards the concept by those organizations which are searching for sustainable future.

An idea of two-dimensional trust is more usually found. The studies of inter-corporate trust, the first dimension involves the partner's objective credibility as the first dimension that includes the attribution of capability and integrity with the involvement of willingness and ability to keep promises. On the other hand trust contains the attribution of benevolence, that corresponds to the partner's good intentions, his or her perceived willingness to pay attention to the other's needs (Doney and Cannon 1997; Ganesan and Hess , 1997).

\section{Literature Review}

\subsection{Customer loyalty}

Customer loyalty is defined as promise of buyers to purchase particular products, services and brands of an organization over a consistent period of time, irrespective of competitor's new products and innovations and these customers are not compelled to switching (Oliver, 1999). It is similar as the maintenance of long term relationship between customer and the organization (Gundlach,Achrol \& Mentzer, 1995; Anderson and Weitz 1992). The term loyalty behavior can be used in several different terms but basically it is considered as the intention of the buyers to make the purchases again and again to build a continuous relationship with the organization (Dick and Basu, 1994; Fornell, 1992). Most frequently loyalty is calculated as a straight outcome to customer satisfaction (Heskett, Sasser, \& Schlesinger, 1997). But some recommend that gratifying customers may not be enough to 
make loyal customers (Fornell, 1992). For example, circumstances like a consumers time constraints, monetary condition, effort perceptions, risk perceptions, or private distinctiveness may donate openly to loyalty performance or form the authority of satisfaction (Lam et al., 2004). Customer loyalty can be attained by recognizing the client needs, organizing them, and accomplishing those. Customer loyalty and customer satisfaction both al're known as a instrument to build up and achieve consistent competitive advantage (Ali et al.,2010). To generate and preserve customer loyalty is fetching an essential role in service industry (Khokhar et al., 2011). In case of service industry in order to make dedicated clients, consistency factor is very significant and have a strong role and pressure on minds of consumers (Khokhar et al., 2011). Loyalty of client is accountable for productivity and expansion of a business, is optimistic for corporation because it engages nonstop purchase of a products and services for a longer duration of time (Khokhar et al., 2011). Customer loyalty is interconnected to the constant subsistence of firm. It is the significant measure that corporations need to adopt if they desire to be mature (John, 2011).

\subsection{Customer Satisfaction}

Customer satisfaction is, in general, an attitude shaped on the basis of experience after clients acquire a product or use a service and pay for them (Fornell, 1992). It is an indication of being pleased with product or a service. Satisfaction is the measurement of the experience of working together with a service provider till the present point of time, and it is used by consumers to expect future experience. Contentment is one of the previous circumstances of customer loyalty. In earlier studies, contentment or satisfaction is directly affecting client loyalty (Dick and Basu 1994). Satisfaction may not always be the sole reason of customer's loyalty. Although it can be said that loyalty is associated with satisfied customers. Satisfaction appears after consumption of some product or service which is the result of actual and expected utility of product (Khokhar et al., 2011). Since the buying behaviors, patterns, needs, and wants, satisfaction level of all the customers are different therefore it is difficult to measure which particular product or service offered will be giving contentment to particular group of customers (Maiyaki et al., 2011. There is positive relationship between satisfaction and customer's loyalty, consequently more the chances of sustained survival of an organization. Marketing and management departments are strongly interrelated (Ahmed et al., 2010).

Therefore, the subsequent hypothesis is tested.

H1: There is positive relationship between customer satisfaction and customer loyalty.

\subsection{Trust}

In literature, trust has been studied extensively. Trust is defined as a belief of one party that other party will be fulfilling their needs and wants. As far as services are concerned, trust is the confidence that customers have on the provider of services to fulfill their needs. Generally trust can be defined as confidence that one party has on another because of honesty and reliability of the other partner (Morgan \& Hunt, 1994). This description can be theoretically applied in diverse situations, including exchanges of goods and services. Doney and Cannon 
(1997) study that trust is formed of two aspects: perceived credibility and benevolence. Some also suggest two levels of trust. The first level is trust of customer on an individual and the second level represents the trust of customer on an institution. Trust is a significant intervening factor between behavior of customers before and after the purchase of particular product. It results in the long-term loyalty and makes stronger the association between the two parties. Trust is considered as a special psychological state as it is in the case of loyalty and it can only occur in certain affairs. When a customer trusts a firm, he or she has the strong confidence in quality of product and services of the organization. Trusting an organization is considered as far beyond the loyalty with an organization.

In my research, I am concerned with the direct effects of trust and satisfaction, as a part of repute on the customer loyalty. The most commonly found idea of trust is two dimensional. The first dimension is related to creditability of other partner in objective terms which includes the attributions of honesty, reliability, and keeping the promises. The other dimension consists of benevolence that is the fair intentions of the partner to fulfill the needs of the other partner (Doney \& Cannon 1997).

Therefore the hypotheses are

$\mathrm{H} 2$ : There is a positive relationship between trust and customer loyalty.

H3: There is positive relationship between trust and customer satisfaction.

\subsection{Reputation}

Reputation is usually considered as the assessment in which a thing or any person is commonly held, as a name or favorable standing or as the way in which a particular person or thing is known for. Reputation is a way to solve the problem of experience goods and services. it has been determined the relationship between loyalty and reputation of the organization and finally concluded that reputation of firm is strongly associated with loyalty as far as public sector is concerned but this point was not further discussed. The relationship between loyalty and image of firm is drawn by the European Customer Satisfaction. Many accounts of reputation use the terms image and reputation interchangeably.

Currently, there are many definitions of business reputation (Chun, 2005); each academic regulation offers its own point of view (Chun, 2005). Some researchers have discovered status from a multi-stakeholder viewpoint - a corporation has more than one reputation.

Corporate reputation has no single perfect definition. It is mostly described in terms of global valuation. There are a lot of ways of measuring the reputation of firm as there are many disciplines in academic study. There are various ranking scales based on measurements. The fortune or the financial times have devised various ranking measures in order to provide the companies with various listings. They only compare which company is better but do not give the reason that how it is better. The respondents are asked to rate the reputation of the company on the basis of the measurements used. They do not give any idea regarding the comparison of firms within the same and different industries. But still they measure the firm specific factors based on the perceptions of the target stakeholders. 


\section{Macrothink}

Research has shown that the reputation of the firm affects the trust level of the customers (e.g. Lee 2005; Lacey, 2007 ), but in turn, corporate brand relationship is also strengthened by the trust (e.g. Lacey,2007; Gronross,1997; O’Malley \& Prother 2004). Relationship building is tactically favorable activity in customer marketing and it results in to long lasting profitability and success of an organization (Morgan and Hunt 1999). Higher customer satisfaction, retention, growth of firm and profitability is attained by building long term relationships with the customers (Gronroos, 1997). The long term relationship with the customers results in repeated purchases of goods and services.

The most important term in forming the long lasting relationship with the customers is trust. (e.g Gronroos, 1997; O’Malley \& Protthero 2004; Lacey,2007). The focus of the relationship is on long term association in contrast to situation based short term benefits to keep the customers in permanent relationship, an appropriate degree of trust is required.

In my point of view, the corporate image is considered as an emotional component and psychological dimension is considered in terms of corporate reputation, which contributes to their development. These dimensions are apparent because of the consumer's thoughts and viewpoints which are based on the previous actions of the firm. The quality of services can only be determined after their consumption therefore the intangible corporate image is an effective means of determining the outcomes associated with production process and therefore they are considered as reliable tool to determine the ability of the firm to satisfy its customers.

After discussion the following hypothesis will be tested.

H4: There is positive relationship between reputation and customer loyalty.

H5: There is positive influence of reputation on customer satisfaction.

H6: There is positive relationship between reputation and trust. 


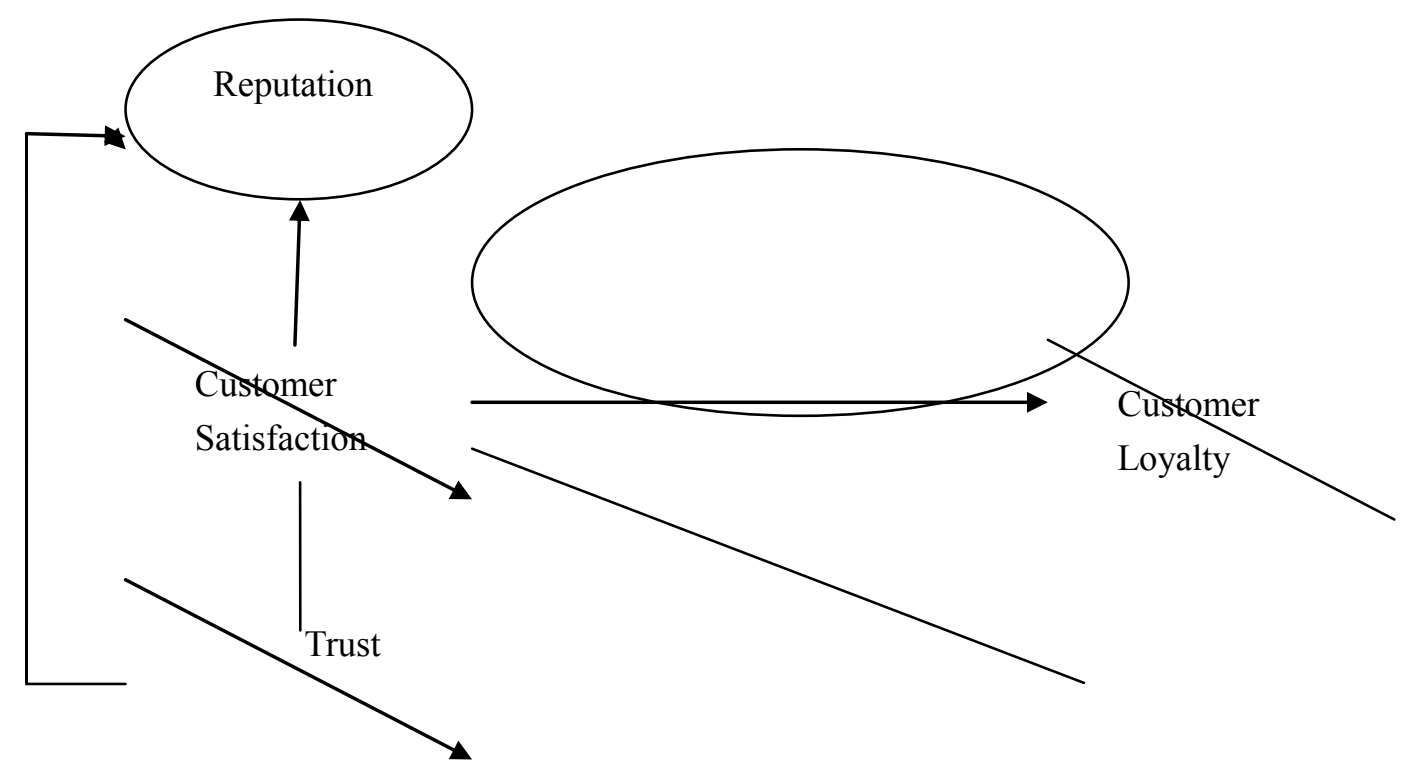

\section{$\underline{\text { Research Model }}$}

\section{Research Methodology}

This is a descriptive type of research in which the purpose is to explain some particular phenomenon. Customer loyalty is main construct to be explained in this research paper. As defined by Creswell 1994 descriptive researches are to be aimed to describe the current situation rather than to interpret or make judgment. As far as objective of this type of research is concerned the hypothesis have been developed and verified to reflect the prevailing situation.

\subsection{Sample/Data}

The research is conducted by taking data from 150 respondents who are asked to contribute to fill a questionnaire that is self administered. The population is taken from Bahawalpur City of Pakistan. All the respondents are the users of Nishat Linen brand. The technique used is non-probability sampling, also known as convenience sampling. The data is collected by the users of the particular brand who were easily accessible. All the users from Islamia University, Quid-E-Azam medical college, Allama Iqbal College, National College Of Business Administration And Economics and different banks from Bahawalpur city are chosen. Both the students and professionals are sample of my research.

\subsection{Instruments and Measures}

The research instrument is designed to measure the inter-relationship of reputation, customer satisfaction, and trust on customer loyalty. On the other hand the respondent's characteristics information is gathered to note the variations in different kinds. There are two sections of questionnaire. First section contains the respondents personal information as well as the demographic variables include gender, age, income, education and status where as the latent variables of second section are discussed before. 


\section{Macrothink}

The already established scales are used for measurement. Reputation contains three items by Bayraktar et al 2012 (Measuring the efficiency of customer satisfaction and loyalty for mobile phone brands with DAE) trust (Fletcher and Peters,1997; Fournier,1994;Hess,1995; Banavent and N'Goala ,2001;Sirieix and Dubois,1999; Chaudhari and Holbrook 2001; ),customer satisfaction contains five items by Oliver (1980) and customer loyalty contains three items by Strazzieri, Le Roux and Chandon(1997) (proposal for a multidimensional brand trust scale by Patricia Gurviez).

Scale with items of the study

Table 1

\begin{tabular}{|c|c|c|c|}
\hline No & Variables & Items & Reference \\
\hline \multirow{3}{*}{1} & \multirow{3}{*}{ Reputation } & $\begin{array}{l}\text { Use of this brand (NISHAT LINEN) } \\
\text { is being reliable }\end{array}$ & \multirow[b]{3}{*}{$\begin{array}{r}\text { Bayraktar et al } \\
2012\end{array}$} \\
\hline & & $\begin{array}{l}\text { This brand (NISHAT LINEN) is } \\
\text { innovative and forward looking }\end{array}$ & \\
\hline & & $\begin{array}{l}\text { This brand (NISHAT LINEN)is } \\
\text { adding value to user(Prestige) }\end{array}$ & \\
\hline \multirow{3}{*}{2} & \multirow{3}{*}{ Trust } & $\begin{array}{l}\text { This brand (NISHAT LINEN) makes } \\
\text { me feel safe }\end{array}$ & \multirow{3}{*}{ Fournier, 1994} \\
\hline & & $\begin{array}{l}\text { I trust the quality of this brand } \\
\text { (NISHAT LINEN) }\end{array}$ & \\
\hline & & $\begin{array}{l}\text { Buying this brand (NISHAT LINEN) } \\
\text { is a guarantee of quality }\end{array}$ & \\
\hline & \multirow[b]{3}{*}{ Customer satisfaction } & $\begin{array}{l}\text { I am satisfied with this brand } \\
\text { (NISHAT LINEN) }\end{array}$ & \multirow[b]{3}{*}{ Oliver (1980) } \\
\hline & & $\begin{array}{l}\text { My choice to use this brand } \\
\text { (NISHAT LINEN) was a wise one }\end{array}$ & \\
\hline & & $\begin{array}{l}\text { This is one of the best brands } \\
\text { (NISHAT LINEN) I could have }\end{array}$ & \\
\hline
\end{tabular}




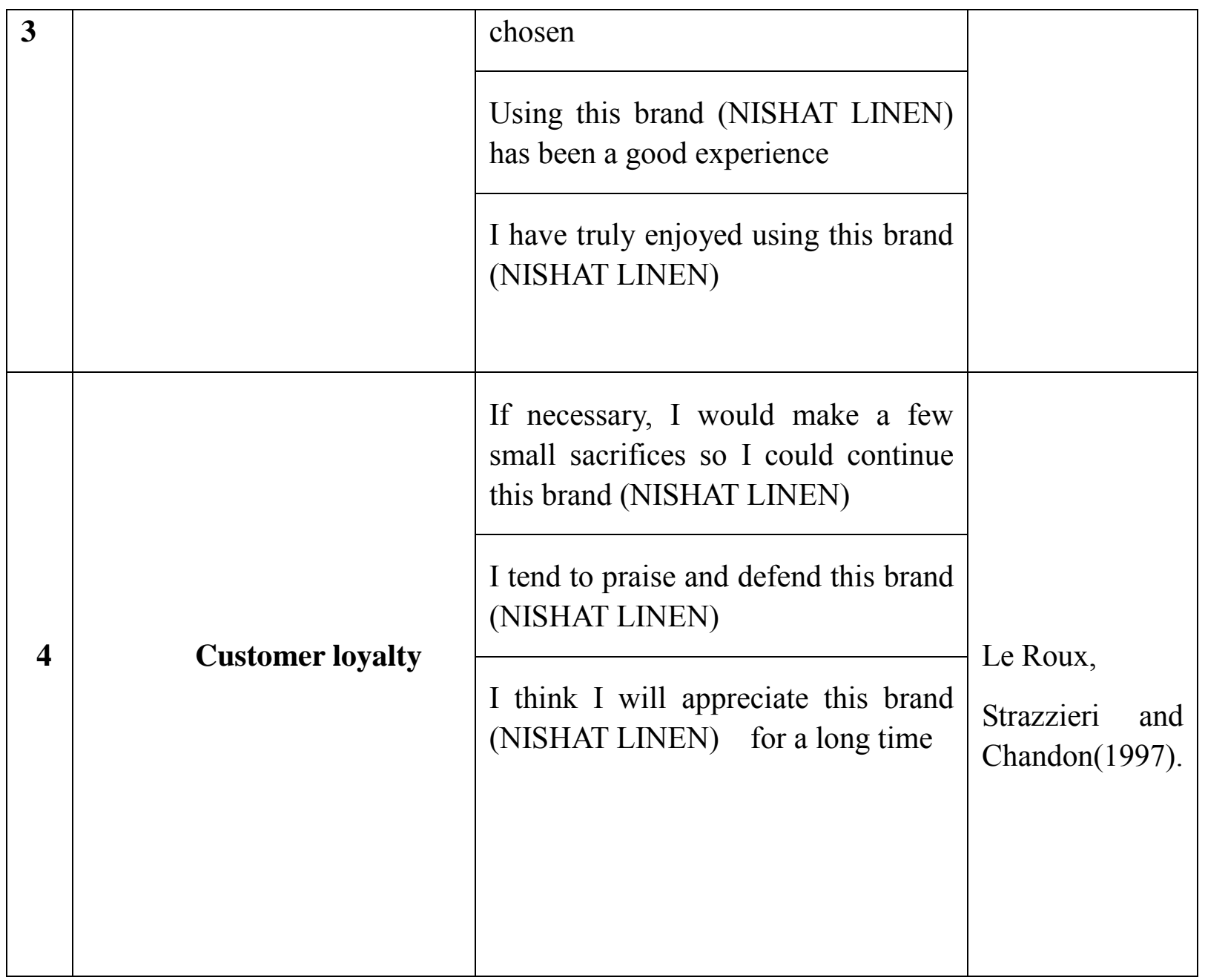

The five point Likert scale is used 1 for strongly agree to 5 for strongly disagree.

\subsection{Procedure}

Total 200 people were selected as mentioned above and questionnaire was distributed among them. 150 questionnaires were received that were filled correctly and added in to the research. Before giving them questionnaires they were told about the purpose of the study for better understanding in order to fill it properly. The data received was entered in SPSS sheet for further analysis.

\subsection{Reliability Analysis}

The overall chronbach alpha of customer loyalty questionnaire is 0.724 that is highly acceptable. The prescribed value is 0.60 by (1998) Moss et al and 0.50 Nunnally (1970). It shows the reliability and validity of instrument to measure the consumer's responses for customer loyalty. 
Table : Reliability Analysis of Measurements Instrument

\begin{tabular}{|l|c|c|}
\hline \multicolumn{1}{|c|}{ Scales } & Items & Cronbach Alpha \\
\hline Reputation & 3 & 0.697 \\
Trust & 3 & 0.690 \\
Customer Satisfaction & 5 & 0.813 \\
Customer Loyalty & 3 & 0.699 \\
\hline
\end{tabular}

\section{Hypothesis Testing}

The personal and demographic profile of the respondents like status, education, income, age and gender are given in the below table.

Table 3: Profile of the Respondents

\begin{tabular}{|c|c|c|c|}
\hline Variables & Category & Frequency & Percentage \\
\hline Gender & $\begin{array}{l}\text { Male } \\
\text { Female }\end{array}$ & $\begin{array}{r}25 \\
40\end{array}$ & $\begin{array}{l}15.2 \\
84.8 \\
\end{array}$ \\
\hline Age & $\begin{array}{lc}20-25 & \text { Years } \\
25-30 & \text { Years } \\
30-35 & \text { Years } \\
35-40 & \text { Years } \\
\text { 40-45 } & \text { Years } \\
\text { Above 45 years } \\
\end{array}$ & $\begin{array}{r}106 \\
28 \\
14 \\
07 \\
04 \\
06 \\
\end{array}$ & \begin{tabular}{r|r|}
64.2 \\
17.0 \\
8.5 \\
4.2 \\
2.4 \\
3.6
\end{tabular} \\
\hline Income(Rs/month) & $\begin{array}{l}\text { Below } \quad 15000 \\
15000-25000 \\
25000-35000 \\
35000-45000 \\
45000-55000 \\
\text { Above 55000 }\end{array}$ & $\begin{array}{l}82 \\
32 \\
20 \\
07 \\
06 \\
18\end{array}$ & $\begin{array}{r}49.7 \\
19.4 \\
12.1 \\
4.2 \\
3.6 \\
10.9\end{array}$ \\
\hline Education & $\begin{array}{l}\text { Matriculation } \\
\text { Inter } \\
\text { Bachelor } \\
\text { Masters } \\
\text { MS/M.Phil } \\
\text { PHD } \\
\end{array}$ & $\begin{array}{r}2 \\
15 \\
67 \\
68 \\
13 \\
00\end{array}$ & $\begin{array}{r}1.2 \\
9.1 \\
40.6 \\
41.2 \\
7.9 \\
00 \\
\end{array}$ \\
\hline Status & $\begin{array}{l}\text { Student } \\
\text { Employed } \\
\text { Businessman } \\
\text { Unemployed } \\
\text { Housewife }\end{array}$ & $\begin{array}{l}95 \\
52 \\
04 \\
04 \\
10\end{array}$ & \begin{tabular}{|r|}
57.6 \\
31.5 \\
2.4 \\
2.4 \\
6.1
\end{tabular} \\
\hline
\end{tabular}




\section{Macrothink

\subsection{Hypothesis Testing}

\subsubsection{Customer satisfaction and customer loyalty}

As the results or regression test mentioned below there is significant positive relationship between customer satisfaction and customer loyalty with the results $(\beta=0.485)$ and $(p<0.01)$. Customer Loyalty is $48 \%$ influenced by customer satisfaction. The results support to H1. This is the strongest relationship of customer satisfaction on terms of customer loyalty.

\subsubsection{Trust and customer loyalty}

The result shows that there is significant and positive relationship between trust and customer loyalty. The $(\beta=0.436)$ and $(p<0.01)$ that shows trust's affects $43 \%$ to customer loyalty, the second influential factor on customer loyalty in this research. The result supports to H2.

\subsubsection{Trust and customer satisfaction}

Again the $\mathrm{H} 3$ shows the significant relationship between trust and customer satisfaction according to regression analysis tests where $(\beta=0.647)$ and $(\mathrm{p}<0.01)$. Here trust has positive $64 \%$ influence on customer satisfaction. It supports H3. Trust is the second highest valued construct that affects customer satisfaction.

\subsubsection{Impact of reputation on customer loyalty, customer satisfaction, and trust}

Regression results have proved that reputation has positive and significant influence on customer loyalty, customer satisfaction, and trust. The values of reputation and customer loyalty are $(\beta=0.377)$ and $(p<0.01)$ that shows positive but comparatively weak relationship of reputation rather than other relationships. There is only $37 \%$ contribution of reputation in retaining the existing customers. this is the support of $\mathrm{H} 4$.

The second positive and significant relationship of reputation is with customer satisfaction. The values that have drawn from regression analysis are $(\beta=0.577)$ and $(p<0.01)$ that shows that customer satisfaction counts $57 \%$ in reputation.H5 is supported by this result

The third and most influential relationship of reputation is with trust. The analysis provides the values $(\beta=0.708)$ and $(p<0.01)$ that supports the fact that trust adds $70 \%$ in reputation. The results validate $\mathrm{H} 6$ and conclude the positive and significant relationship. 
The following table summarizes the results of regression analysis.

Table 4: Regression Results

\begin{tabular}{|c|c|c|c|c|c|c|}
\hline Hypothesis & Model variable & Estimates & S.E & C.R & $\mathbf{P}$ & Results \\
\hline H1 & $\begin{array}{l}\mathrm{CS} \\
\mathrm{CL}\end{array}$ & 0.485 & 0.080 & 7.080 & 0.00 & Supported \\
\hline $\mathbf{H} 2$ & $\begin{array}{l}\text { Trust } \\
\text { CL }\end{array}$ & 0.436 & 0.074 & 6.182 & 0.00 & Supported \\
\hline H3 & $\begin{array}{l}\text { Trust } \\
\text { CS }\end{array}$ & 0.647 & 0.054 & 10.825 & 0.00 & Supported \\
\hline H4 & $\begin{array}{l}\text { REP } \\
\text { CL }\end{array}$ & 0.377 & 0.082 & 5.202 & 0.00 & Supported \\
\hline H5 & $\begin{array}{l}\text { REP } \rightarrow \\
\mathrm{CS}\end{array}$ & 0.577 & 0.061 & 9.008 & 0.00 & Supported \\
\hline H6 & $\begin{array}{l}\text { REP } \rightarrow \\
\text { Trust }\end{array}$ & 0.708 & 0.059 & 12.794 & 0.00 & Supported \\
\hline
\end{tabular}

Customer satisfaction $=\mathrm{CS}$, Customer Loyalty $=\mathrm{CL}$, Reputation $=$ REP 


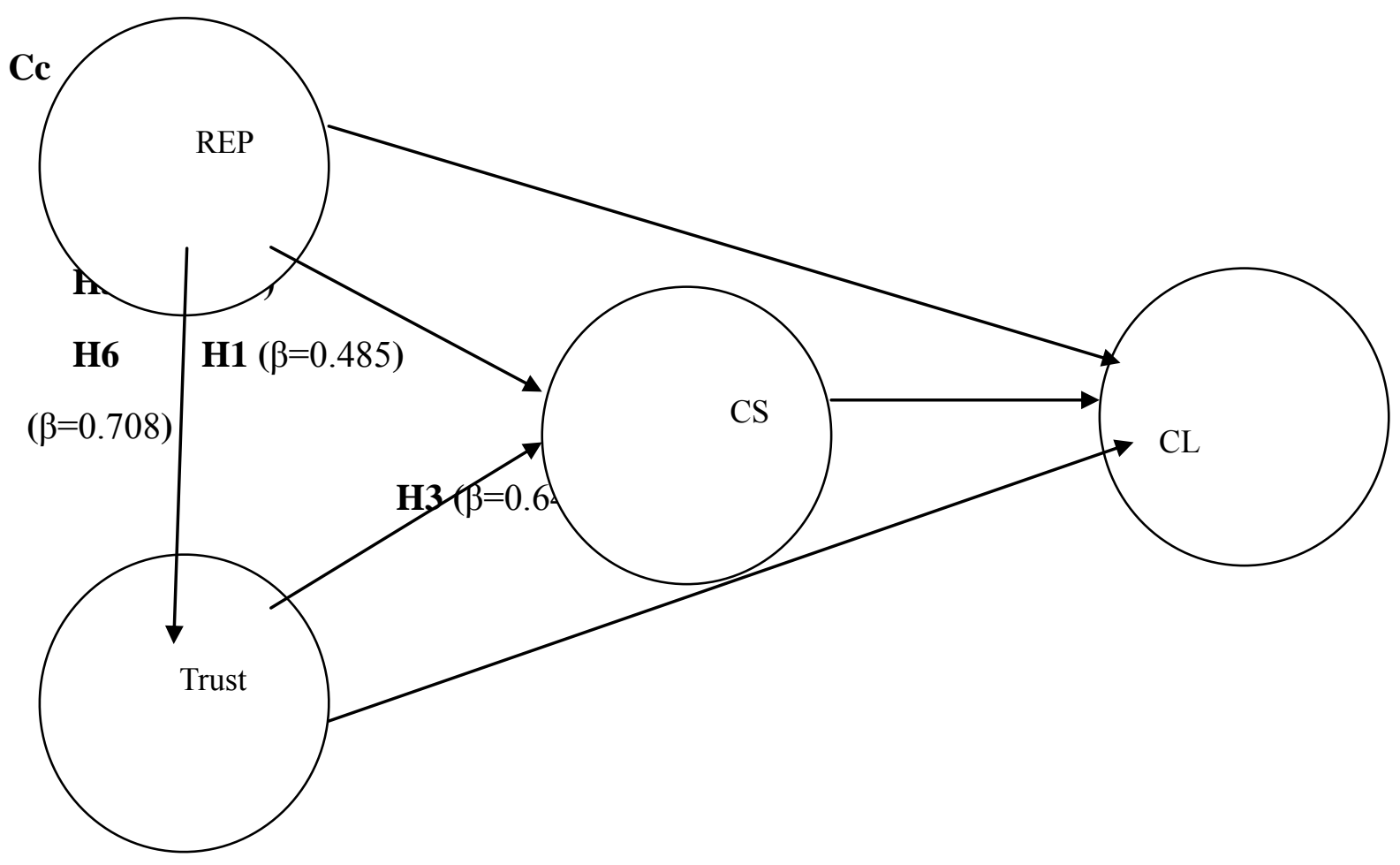

Structural Model Result

\section{Discussion}

The research study is conducted for the importance of customer's loyalty in the present era. The businesses of the entire world are running and prospering not only due to the customers but loyal customers. A loyal customer is defined as a person who purchases or intends to purchase a specific brand repeatedly on different basis. Customer loyalty is a difficult multi-dimensional construct that is built on two components, attitude and behavior. Both the concepts have a slight difference in its operational definition but here in the studies there is parallel footing of attitude and behavior in measuring customer loyalty. It takes 5 to 10 percent more cost to attract new customers rather than retaining the loyal one . So retain customer loyalty is cost efficient strategy that can be attained by customer satisfaction, trust and reputation.

Customer satisfaction is the major driver of customer loyalty in my studies. Customer satisfaction is defined in many ways, the most frequent conceptualization that has seen repeatedly to have gained the response states i.e.: a customer's post purchase assessment about products or services is satisfaction. Customer satisfaction in terms of customer loyalty is also commonly assumed to be a major determinant of regular sales. Satisfied customers return to buy more. Not only the customer satisfaction impacts on customer loyalty but it performs the role of advertising of product or service in the form of word-of-mouth. He, who is satisfied, is loyal and communicates the positive about the product or services more or less nine others. 


\section{Mll Macrothink}

Journal of Public Administration and Governance

ISSN 2161-7104

2014, Vol. 4, No. 3

Trust is another factor that affects customer loyalty. Their trust and brand trust is having same meaning. When the customer is loyal towards a product or service he is basically trusting in it. Brand trust is a promise between the brand and the customer that it is going to fulfill its customer's need according to his desires. As I have conducted my studies regarding clothing brand of Nishat Linen, wearing it is usually considered the status symbol. Nishat Linen is basically a prestigious brand having high price high quality. So it is promising its customers to give them status in the society and showing them distinguish among the others. Another relation that strengthens customer's satisfaction is trust. When anything is trust worthy for a customer it is naturally satisfying him. The second highest impact on customer satisfaction is trust according to the research results other than customer loyalty.

Reputation, brand reputation, corporate image and corporate reputation in some situations are used in same meaning. Here the weakest impact of reputation is observed on customer loyalty in comparison with other variables. But the impact of reputation on trust is giving the strongest results and the impact of reputation on customer satisfaction is on second number. In short reputation overall is a strong construct. In my studies the brand reputation is playing a significant role on customer loyalty and customer satisfaction as well. People have an image of Nishat Linen in their minds. The literature concludes fairly that there is a strong connection between brand trust and corporate reputation, where reputation plays a key role to create trust in an organization. (Foam burn and Van Riel ,1997; Lacely 2007). Moreover, in the studies of reputational scale the trust is mostly incorporated as an integral part of corporate reputation. (e.g. Fombrun et al 2000). In my present research work I am going to measure the impact of reputation on trust. The studies also reply for the qualitative studies of interrelationship between reputation and trust (Xie and keh, 2009).

The name of Nishat Linen is enough for trust, customer satisfaction, and loyalty. Reputation is not only viewed in the perception of branding and marketing, but is required to judge firm's characteristics). However, reputation as an external phenomenon and output can be considered as the result of interior conclusion and action that form the firm, internal branding, and employees (Chun, 2005).

\section{Recommendations}

This research is practically important for implementation. No doubt, there is an intense competition among the saturated market of clothing. An incremental focused approach must be adopted to get competitive edge and success for survival in this unpredictable market. One way to retain customers is scientifically sound marketing that is advertising. Customers are now brand conscious and need prestige. For fulfilling both the requirements they must have trust and satisfaction and must be confident about reputation of brand that make them feel distinguished among the people. So to achieve this challenging task the minds of the audience must be captured to make them realize that their choice of this particular brand is absolutely correct and it is possible due to effective advertising.

Nishat Linen is a brand that has specific outlets particularly in big cities. The company must concentrate towards market development as well as market penetration. It must strive hard to sustain its clothing quality and must enhance its designs and prints. All these discussed 
factors have considerable contribution in customer loyalty.

This is the era of technology. World is becoming global village. People have a lot of access towards internet shopping. They have a number of alternatives to choose without visiting outlets physically. So one more suggestion for Nishat Linen Company is to start online shopping to give ease to its customers that are an additional point regarding reputation, trust, customer satisfaction and customer loyalty.

\section{Limitations and Future Research}

Time limit was the main constraint. A short time period was given to conduct this research. A limited No. of people is the user of this brand. A short sample size of 200 people was selected who were the actual users of this brand. It was very hard to access them due to time constraint. Only Bahawalpur City was selected as geographic area. This is not a very big city. In cities like Bahawalpur people are not well aware and educated than the big cities about brands. So it was a bit difficult to make them understand about the purpose of studies before survey.

In future a vast geographic area where the outlets of the brand situated must be chosen. By this the researcher will be able to select large sample size and the results of the study will be more significant by taking the opinion of more people.

While conducting studies it is noticed that the variables being studied are not sufficient for studies. Some other constructs like perceived price, perceived value, and switching barriers can be added in the research for better results regarding retaining customers

\section{References:}

1. Ahmed, I., Nawaz, M. M., Usman, A., Shaukat, M. Z., Ahmed, N., \& Rehman, U. W. (2010). A mediation of customer satisfaction relationship between service quality and repurchase intentions for the telecom sector in Pakistan: A case study of university students. African Journal of Business Management, 4(16), 3457-3462.

2. Ali, I., Rehman, K. U., Yilmaz, A. K., Nazir, S., \& Ali, J. F. (2010). Effects of corporate social responsibility on consumer retention in cellular industry of Pakistan. African Journal of Business Management, 4(4), 475-485

3. Anderson, E., \& Weitz, B. (1992). The use of pledges to build and sustain commitment in distribution channels. Journal of marketing research, 18-34.

4. Bayraktar, E., Tatoglu, E., Turkyilmaz, A., Delen, D., \& Zaim, S. (2012). Measuring the efficiency of customer satisfaction and loyalty for mobile phone brands with DEA. Expert Systems with Applications, 39(1), 99-106

5. Beerli, A., Martin, J. D., \& Quintana, A. (2004). A model of customer loyalty in the retail banking market. European Journal of Marketing, 38(1/2), 253-275.

6. Bloemer, J., De Ruyter, K., \& Peeters, P. (1998). Investigating drivers of bank loyalty: 


\section{Macrothink}

Journal of Public Administration and Governance ISSN 2161-7104 2014, Vol. 4, No. 3

the complex relationship between image, service quality and satisfaction. International Journal of Bank Marketing, 16(7), 276-286.

7. Brown, T. J., \& Dacin, P. A. (1997). The company and the product: corporate associations and consumer product responses. The Journal of Marketing, 68-84.

8. Castro, G. M., López, J. E. N., \& Sáez, P. L. (2006). Business and social reputation: exploring the concept and main dimensions of corporate reputation.Journal of Business Ethics, 63(4), 361-370.

9. Chen, M.-F., \& Mau, (2007). The impacts of ethical sales behaviour on customer loyalty in the life insurance industry. The Service Industries Journal , 29 (1), 59-74.

10. Creswell, J.W. (1994) Research Design: Qualitative \& Quantitative Approaches. London: SAGE Publications

11. Chun, R. (2005). Corporate reputation: Meaning and measurement. International Journal of Management Reviews, 7(2), 91-109.

12. Cretu, A. E., \& Brodie, R. J. (2007). The influence of brand image and company reputation where manufacturers market to small firms: A customer value perspective. Industrial Marketing Management, 36(2), 230-240.

13. Chaudhuri, A., \& Holbrook, M. B. (2001). The chain of effects from brand trust and brand affect to brand performance: the role of brand loyalty. The Journal of Marketing, 81-93.

14. Cronin Jr, J. J., \& Taylor, S. A. (1992). Measuring service quality: a reexamination and extension. The journal of marketing, 55-68.

15. Cronin Jr, J. J., Brady, M. K., \& Hult, G. T. M. (2000). Assessing the effects of quality, value, and customer satisfaction on consumer behavioral intentions in service environments. Journal of retailing, 76(2), 193-218.

16. Deng, Z., Lu, Y., Wei, K. K., \& Zhang, J. (2010). Understanding customer satisfaction and loyalty: An empirical study of mobile instant messages in China. International Journal of Information Management, 30(4), 289-300.

17. Dick, A. S., \& Basu, K. (1994). Customer loyalty: toward an integrated conceptual framework. Journal of the academy of marketing science, 22(2), 99-113.

18. Doney, P. M., \& Cannon, J. P. (1997). An examination of the nature of trust in buyer-seller relationships. the Journal of Marketing, 35-51.

19. Elliott, R. H., Elliott, R., \& Percy, L. (2007). Strategic Brand Management Pb. Oxford University Press.

20. Fletcher, K. P., \& Peters, L. D. (1997). Trust and direct marketing environments: a consumer perspective. Journal of Marketing Management,13(6), 523-539.

21. Fombrun, C. J., Gardberg, N. A., \& Sever, J. M. (2000). The reputation quotient: A 
multi-stakeholder measure of corporate reputation. Journal of Brand Management, 7(4), 241-255.

22. Fombrun, C., \& Shanley, M. (1990). What's in a name? Reputation building and corporate strategy. Academy of management Journal, 33(2), 233-258.

23. Fombrun, C., \& Riel, C. V. (1997). The reputational landscape. Corporate reputation review, 1-16.

24. Fornell, C. (1992). A national customer satisfaction barometer: the Swedish experience. the Journal of Marketing, 6-21.

25. Fornell, C., \& Wernerfelt, B. (1988). A model for customer complaint management. Marketing Science, 7(3), 287-298.

26. Fornell, C., Johnson, M. D., Anderson, E. W., Cha, J., \& Bryant, B. E. (1996). The American customer satisfaction index: nature, purpose, and findings. The Journal of Marketing, 7-18.

27. Ganesan, S., \& Hess, R. (1997). Dimensions and levels of trust: implications for commitment to a relationship. Marketing letters, 8(4), 439-448.

28. Garbarino, E., \& Johnson, M. S. (1999). The different roles of satisfaction, trust, and commitment in customer relationships. the Journal of Marketing, 70-87.

29. Grönroos, C. (1997). Keynote paper From marketing mix to relationship marketing-towards a paradigm shift in marketing. Management decision, 35(4), 322-339.

30. Gundlach, G. T., Achrol, R. S., \& Mentzer, J. T. (1995). The structure of commitment in exchange. The Journal of Marketing, 78-92.

31. Gurviez, P., \& Korchia, M. (2003). Proposal for a multidimensional brand trust scale. 32nd EMAC Conference2glasgow Marketing: Responsible and Relevant,5, 56258.

32. Halstead, D., \& Page, T. J. (1992). The effects of satisfaction and complaining behavior on consumer repurchase intentions. Journal of Consumer Satisfaction, Dissatisfaction and Complaining Behavior, 5(1), 1-11.

33. Heskett, J. L., Sasser, W. E., \& Schlesinger, L. A. (1997). Service profit chain. SimonandSchuster. com.

34. Hirschman, A. O. (1970). Exit, voice, and loyalty: Responses to decline in firms, organizations, and states (Vol. 25). Harvard university press.

35. Nunnally, JC. (1970). Introduction to Psychological Measurement. New York: McGraw-Hill

36. John, J. (2011). An analysis on the customer loyalty in telecom sector: Special reference to Bharath Sanchar Nigam limited, India. Afr. J. Marketing Manage,3(1), 


\section{Macrothink}

$1-5$.

37. Keh, H. T., \& Xie, Y. (2009). Corporate reputation and customer behavioral intentions: The roles of trust, identification and commitment. Industrial Marketing Management, 38(7), 732-742.

38. Khokhar, S. Z., Hussain, F., Qureshi, T. M., Anjum, I., Samran, A., \& Arshad, R. (2011). Only customer satisfaction and customer loyalty is not enough: A study of Pakistan $^{\text {ee }}$ s telecom sector. Afr. J. Bus. Manag, 5(24), 10176-10181.

39. Kirmani, A., \& Rao, A. R. (2000). No pain, no gain: A critical review of the literature on signaling unobservable product quality. The Journal of Marketing, 66-79.

40. Kristensen, K., Martensen, A., \& Gronholdt, L. (2000). Customer satisfaction measurement at Post Denmark: results of application of the European Customer Satisfaction Index methodology. Total Quality Management, 11(7), 1007-1015.

41. Lam, S. Y., Shankar, V., Erramilli, M. K., \& Murthy, B. (2004). Customer value, satisfaction, loyalty, and switching costs: an illustration from a business-to-business service context. Journal of the Academy of Marketing Science, 32(3), 293-311.

42. Lacey, R. (2007). Relationship drivers of customer commitment. The Journal of Marketing Theory and Practice, 15(4), 315-333.

43. Lee, B. K. (2005). Hong Kong consumers' evaluation in an airline crash: A path model analysis. Journal of Public Relations Research, 17(4), 363-391.

44. Maiyaki, A.A., N.B. Noor and S.S. Mokhtar, 2011. The influence of service quality of mobile phone on customer satisfaction in Malaysia: A students' feedback survey. J. Bus. Manag. Account., 1(1): 79-97

45. .Morgan, R. M., \& Hunt, S. (1999). Relationship-based competitive advantage: the role of relationship marketing in marketing strategy. Journal of Business Research, 46(3), 281- 290

46. .Moss, S., Prosser, H., Costello, H. (1998). Reliability and validity of the PAS-ADD Checklist for detecting psychiatric disorders in adults with intellectual disability. Journal of Intellectual Disability Research.42, 173-183.

47. Oliver, R. L. (1980). A cognitive model of the antecedents and consequences of satisfaction decisions. Journal of marketing research, 460-469.Oliver, R. L. (1997). Satisfaction: A behavioral perspective on the customer.

48. .Oliver, R. L. (1999). Whence consumer loyalty?. the Journal of Marketing, 33-

49. sO'Malley, L., \& Prothero, A. (2004). Beyond the frills of relationship marketing. Journal

of Business Research, 57(11), 1286-1294.

50. .Reichheld, F. F., \& Sasser, W. E. (1990). Zero defections: quality comes to services 
business review, 68(5), 105-111.

51. Rose, C., \& Thomsen, S. (2004). The Impact of Corporate Reputation on Performance:: Some Danish Evidence. European Management Journal, 22(2), 201-210

52. .Manski, D. M., \& Henard, D. H. (2001). Customer satisfaction: a meta-analysis of the empirical evidence. Journal of the academy of marketing science, 29(1), 16-35.

53. .Varnali, K., Toker, A., \& Yilmaz, C. (2009, August). A CONSUMER CENTRIC MODEL FOR MOBILE MARKETING. In 12TH INTERNATIONAL CONFERENCE (p. 100).

54. Westbrook, R.A., Oliver, R.L., 1991. The dimensionality of consumption emotion patterns and consumer satisfaction. Journal of Consumer Research 18 (June), 84-91.

55. .Zeithaml, V. A., \& Bitner, M. J. (1996). Services marketing. Nueva York: McGraw Hill. 